Orientalia Christiana Cracoviensia 10 (2018), s. 19-34

DOI: http://dx.doi.org/10.15633/ochc.2975

Alicja Zofia Nowak

Uniwersytet Jagielloński

\title{
Druki lwowskich wydawców w XVII wieku na rzecz odrodzenia nauczycielskiej posługi kapłana w metropolii kijowskiej
}

\begin{abstract}
Prints of Lvov Publisher In the XVIIth century in the interest of regenerating a teaching service of a priest in Kyiv Metropolitanate. Lvov typographies in the first half of the XVIIth century made efforts to promote and increase the level of teaching in the Kyiv Metropolitanate. Reformers from Lvov led a crusade to renew the custom of proclaiming the Word of God, including through the selection and printing of appropriate patristic translation works and various church books, which were escorted by paratexts, intended for priests (including for church teachers). They also put a lot of effort into forming teachers who were characterized by an appropriate level of knowledge and moral values. These efforts were an important part of the reform which also was undertaken in other educational and publishing centers (or by independent publishers) and directed at the revival of a priest's teaching service in the Kyiv Metropolitanate.
\end{abstract}

Druki lwowskich wydawców w XVII wieku na rzecz odrodzenia nauczycielskiej posługi kapłana w metropolii kijowskiej. Lwowskie typografie już w pierwszej połowie XVII wieku podjęły starania o rozpropagowanie i wzrost poziomu nauczania w metropolii kijowskiej. Reformatorzy ze Lwowa prowadzili krucjatę na rzecz odnowy zwyczaju przepowiadania słowa Bożego m.in. poprzez dobór i druk odpowiednich patrystycznych dzieł przekładowych oraz rozmaitych ksiąg cerkiewnych, które eskortowane były przez nauki paratekstowe, przeznaczone dla kapłanów (w tym również dla cerkiewnych nauczycieli). Włożyli wiele wysiłku w uformowanie nauczycieli, odznaczających się odpowiednim poziomem wiedzy i moralnymi walorami. Starania te były ważną częścią składową reformy podjętej także 
w innych ośrodkach oświatowo-wydawniczych (lub przez samodzielnych wydawców) i ukierunkowanej na odrodzenie nauczycielskiej posługi kapłana w metropolii kijowskiej.

Keywords old print, typography, reform, teaching, Lvov

stary druk, typografia, reforma, nauczanie, Lwów

Księga drukowana (druk ulotny) była jednym z ważnych narzędzi reformy religijnej, której pierwsze przejawy w Kościele wschodnim w Rzeczypospolitej można zaobserwować w XVI wieku1. Znaczna część wydawnictw w XVIXVII wieku była adresowana do kleru, bowiem to środowisko wymagało odnowy moralnej i merytoryczno-intelektualnej. Przeprowadzenie działań naprawczych w obrębie podstawowych dziedzin życia duchowo-religijnego było kluczowym elementem cerkiewnego odrodzenia i gwarantem kontynuacji odnowicielskich procesów, podejmowanych najpierw przez ludzi świeckich, a następnie duchowieństwo ${ }^{2}$, odpowiednio przygotowane do misji nauczycielskiej³.

Pierwszą lwowską drukarnią, zarazem najbardziej produktywną przez cały wiek XVII, była typografia należąca do prawosławnego bractwa stauropigialnego. To w tym warsztacie już w pierwszych dziesięcioleciach XVII wieku ukazały się ważne dla reformy religijnej i kulturalnej księgi liturgiczne, zbiory nauczycielskie, cerkiewne dokumenty, gramatyki będące wsparciem dla prowadzonego tam szkolnego ośrodka i inne pomoce tekstowe ${ }^{4}$. Wzrastająca ich dostępność mogła mieć pozytywny wpływ na moralno-intelektualne formowanie duchowieństwa, była potencjalnym wsparciem dla księży sprawujących nauczycielską posługę.

1 Na ten temat por. B. A. Gudziak, Poczatki drukarstwa i reform w ruskiej Cerkwi, w: B. A. Gudziak, Kryzys i reforma. Metropolia kijowska, patriarchat Konstantynopola i geneza unii brzeskiej, Lublin 2008, s. 159-175.

2 A. Z. Nowak, Reforma duchowieństwa wschodniego w Rzeczypospolitej w świetle ogólnego programu odnowy Kościoła, w: Między Wschodem i Zachodem. Prawosławie i unia, pod red. M. Kuczyńskiej, Warszawa 2017, s. 174-195 (Kultura Rzeczypospolitej w Dialogu z Europą. Hermeneutyka Wartości, 11).

3 Na temat rozwoju homiletyki w omawianym okresie por. M. Kuczyńska, Homiletyka cerkiewna Pierwszej Rzeczypospolitej na pograniczu kultur (do polowy XVII wieku), w: Między Wschodem i Zachodem..., dz. cyt., s. 196-237.

$4 \mathrm{Na}$ temat działalności tego ośrodka wydawniczego por. m.in. I. Isaievych, The Publishing Activities of the Confraternities, w: I. Isaievych, Voluntary Brotherhood Confraternities of Laymen in Early Modern Ukraine, Toronto 2006, s. 200-236 (pierwsze wydanie w języku ukraińskim, Lwów 1966); Ю. Є. Шустова, Документы Львовского Успенского Ставропигийского братства (1586-1788): источниковедческое исследование, Москва 2009. 
Wśród wartościowych dla środowiska duchownego ksiąg należy wymienić w pierwszym rzędzie, przygotowany edytorsko we wspomnianym wyżej lwowskim centrum oświatowo-wydawniczym zbiór przetłumaczonych na język słowiański prac Jana Złotoustego i innych ojców Kościoła (m.in. Bazylego Wielkiego, Izydora z Peluzjum, patriarchy Genadiusza). Tom z 1614

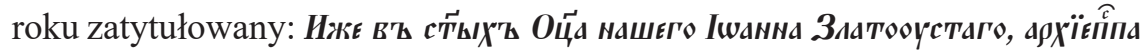

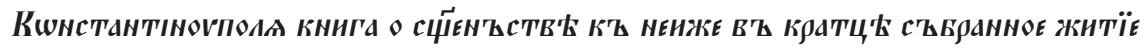

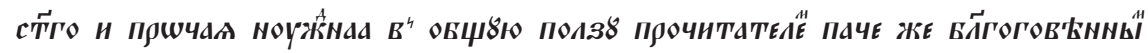

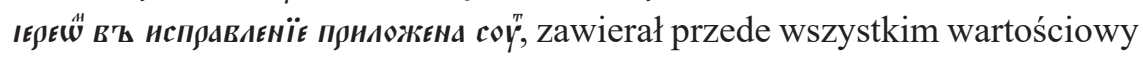
zwłaszcza dla kleru Dialog o kapłaństwie Jana Chryzostoma i żywot ,złotoustego Ojca", zaś drugą część tego obszernego zbioru wypełniły głównie fragmenty jego homilii komentujących listy św. Pawła Apostoła ${ }^{5}$. Zostały one podobnie jak Dialog wydane po raz pierwszy w metropolii kijowskiej, a co szczególnie cenne, dobrane z intencją omówienia kluczowych problemów duszpasterskiej działalności kapłana. Wypisy z homilii w tej sekcji zostały zgrupowane w 30 tematycznych rozdziałach, opatrzonych szczegółowymi tytułami, ułatwiającymi korzystanie z obszernego ich wyboru. Przewijający się w całym zbiorze temat posługi nauczycielskiej został podjęty osobno w rozdziałach 9. oraz $12-21^{6}$.

O znaczeniu pism św. Jana, upowszechnianych w metropolii kijowskiej dzięki drukowi, wspominał Aleksander Bałaban (starosta winnicki) w liście dedykacyjnym skierowanym do biskupa Jeremiasza Tysarowskiego. Działalność wydawnicza Gedeona Bałabana, poprzedniego lwowskiego władyki, któremu śmierć nie pozwoliła wydać prac Jana Złotoustego, została w tym paratekście ukazana jako wyraz pasterskiej troski, aby ,nakarmić

5 Homiletyczne komentarze do listów św. Pawła Apostoła z języka greckiego przełożył na słowiański Cyprian z Ostroga, na temat jego szkolnej i tłumaczeniowej działalności por. К. В. Харламповичъ, Западно-русскія православныя школь 16 и начала 17 въка, Казань 1898, s. 274-275. W tej części zamieszczono także kilka fragmentów z homilii Jana Złotoustego, komentujących Dzieje Apostolskie. Spis artykułów w zbiorze i ich omówienie por. A. Z. Nowak, Bracka oferta wydawnicza a odnowa kaplaństwa w Rzeczypospolitej - wybrane przykłady (pierwsza połowa XVII w.), w: Ośrodki kultury dawnej Stowiańszczyzny i ich znaczenie dziejowe, pod red. M. Kuczyńskiej, J. Stradomskiego, Kraków 2017, s. 181-210 (Krakowsko-Wileńskie Studia Slawistyczne, 12).

6 Jan Chryzostom rozróżniał bardzo wyraźnie trzy rodzaje funkcji związanych z wykonywaniem posługi kapłańskiej: jedna z nich obejmowała wizję kapłana jako strażnika doktryny i tego, który zapewnia jej przekaz, poucza lud i kształtuje jego chrześcijańskie obyczaje (didaskalia), H. de Lubac, Wstęp. Teologia „Dialogu o kapłaństwie”, w: Św. Jan Chryzostom, Dialog o kapłaństwie, przekł. ks. W. Kania, oprac. ks. M. Starowieyski, Kraków 1992, s. 31-32. 
wiernych odczuwających duchowy głód” i ,przynieść wytchnienie wszystkim spragnionym źródła zdrowej nauki"7.

Tom rzeczywiście był wartościowym i bogatym źródłem informacji oraz porad skierowanych do duchowieństwa, szczególnie obszernie został wyłożony problem nauczycielskich powinności prezbitera.

W Dialogu o kaptaństwie - dziele cieszącym się autorytetem w świecie chrześcijańskim nieprzerwanie od IV w., Jan Złotousty wyraził przekonanie, że głoszenie słowa Bożego jest najskuteczniejszym sposobem uzdrawiania dusz ludzkich:

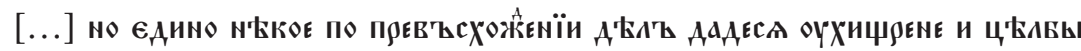

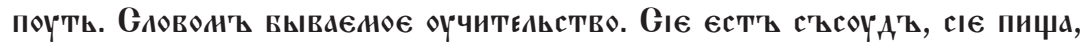

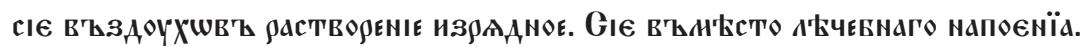

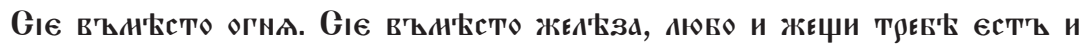

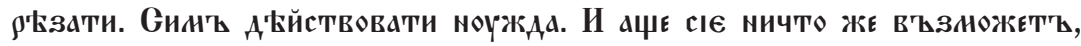

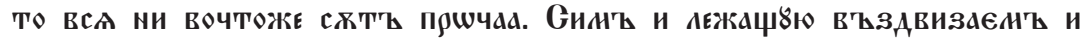

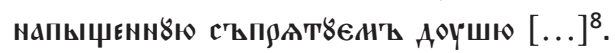

Z powyższej prawdy wynikała kolejna konstatacja, że dusze powierzone przewodnikowi, który pozbawiony jest daru wymowy, wpadają w wielkie niebezpieczeństwo, są niczym łodzie miotane burzą:

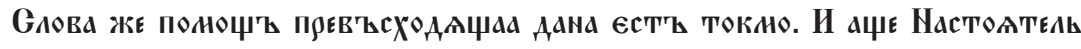

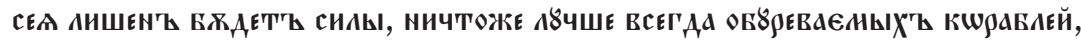

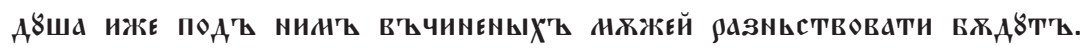

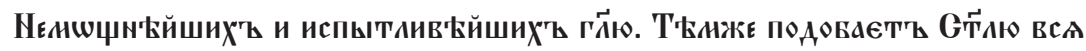
творити ш еже сон стажати Gлова крбпость'

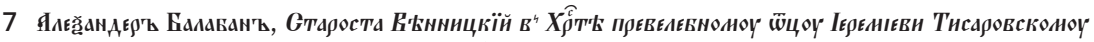

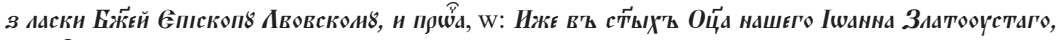

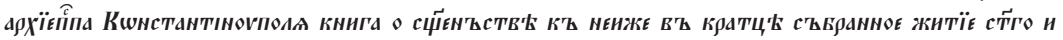

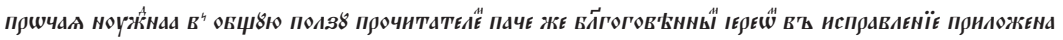
сой, Авовъ 1614, k. 4 nlb.

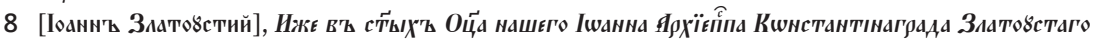

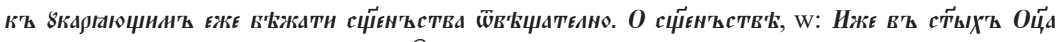

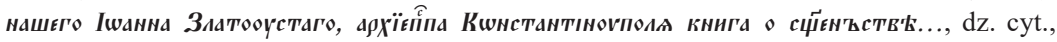
s. $124-125$.

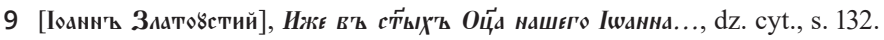




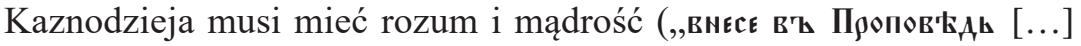

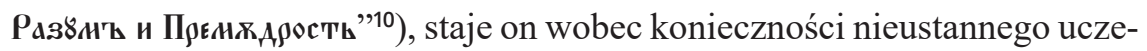
nia się. Obowiązek ten dotyczył wszystkich głosicieli, obejmując także tych, którzy mają siłę wymowy. Według św. Jana biegłość oratora nie jest wynikiem otrzymanego daru natury, ale rezultatem wytrwałej nauki ${ }^{11}$. Poza tym ci, którzy zostali powołani do głoszenia słowa, muszą mieć w tym dziele doświadczenie, ponieważ wskutek ich lenistwa szkodę ponosi wielu ludzi. Najczęściej odwracają się oni od wiary, widząc, że nauczyciel nie potrafi obronić jej prawd ${ }^{12}$.

Mowa chrześcijańska może nie być błyskotliwa ani wyszukana, ale głosiciel słowa musi mieć wiedzę dotyczącą prawd wiary oraz umiejętność ich wyłożenia:

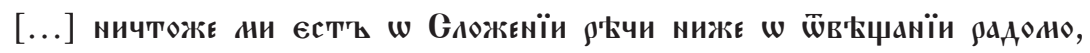

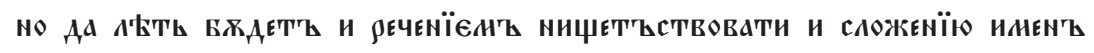

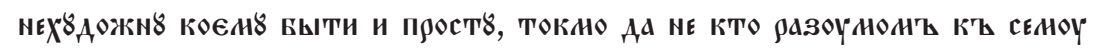

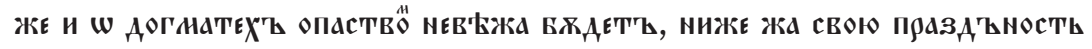
или А'ность покоити Хота ${ }^{13}$.

Nauczyciel powinien zawracać uwagę na odbiorców pouczenia, może się bowiem zdarzyć, że wierni pomimo często głoszonych kazań nie pogłębiają wiary, ani nie odnoszą duchowego pożytku, słuchając mów jedynie dla przyjemności ${ }^{14}$.

Jan Chryzostom wymagał również, aby nauczanie było ustawiczne. Ziarno słowa Bożego należy rzucać bezustannie, bowiem uwaga ludzi,

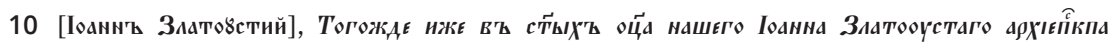

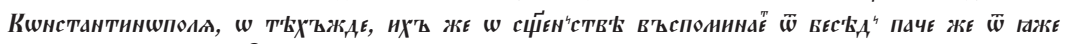

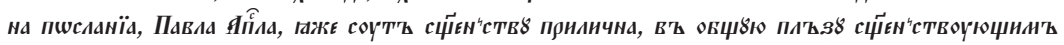

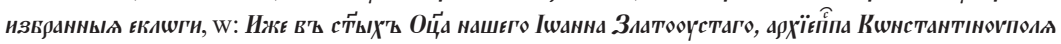
книга o сйєн'ъствъ..., dz. cyt., s. 249. Dotyczy m.in. tego tematu rozdział 9. ze zbioru homilii zamieszczonych w drugiej części tomu (s. 249-254).

11 [Іоаннъ ЗАатовстий], Нже въ сттыХъ Оц̆а нашєго Ішанна..., dz. суt., s. 153.

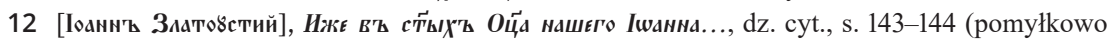
145).

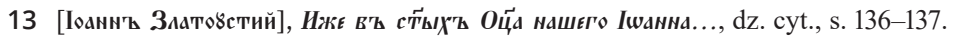

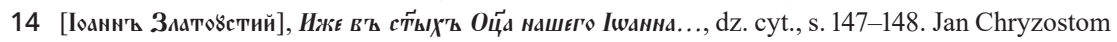
wiele uwagi poświęcił przepowiadaniu słowa Bożego, przywołując wzór św. Pawła, który jak podkreślał, więcej zdziałał słowem niż cudami. Mówca, jak twierdził, musi pracować nad słowem i pamiętać, by nie było ono retoryczną deklamacją dla poklasku, por. M. Starowieyski, Wstęp. Dialog o kaplaństwie, w: św. Jan Chryzostom, Dialog o kaptaństwie, dz. cyt., s. 27. 
którymi kieruje kapłan, jest na co dzień rozpraszana przez rozliczne troski życia ${ }^{15}$. Słowami św. Pawła do ucznia $(1 \mathrm{Tm} 4 ; 13,16)$ nawoływał: Посн४шай

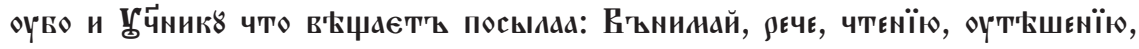

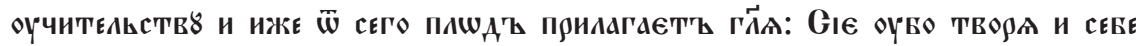
сй́сєши и пос

Temat ten (wraz z powyższym cytatem z listu apostolskiego) powrócił także w drugiej części zbioru, w której rozdział 17. został dedykowany tym, którzy uważali, że nauczanie w Cerkwi jest zbyteczne: На Гйючихъ, гако мє

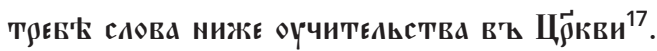

W części homilijnej zbioru znaczna część rozważań była poświęcona moralnym walorom nauczyciela. Powinien być to człowiek czysty, nieskłonny do gniewu i cichy ${ }^{18}$, skromny i pokorny ${ }^{19}$, gorliwy w dziele głoszenia słowa Bożego ${ }^{20}$, a jednocześnie mężny, gotowy na trud i cierpienia ${ }^{21}$.

Najważniejszy i nadpisany nad tym wzorcem postulat dotyczył obowiązkowej zgodności, między postepowaniem nauczyciela i zawartością jego na-

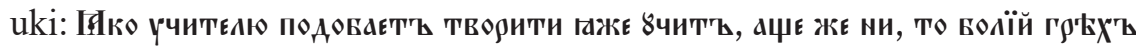

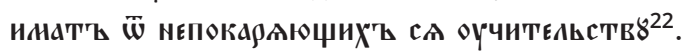

W tej części zbioru zgrupowano także fragmenty homilii św. Jana, w których udzielał rozmaitych praktycznych porad dotyczących sposobu głoszenia w Cerkwi. Odpowiednią recepcję nauki zapewnić miało m.in. nieśpieszne i łagodne przemawianie do wiernych:

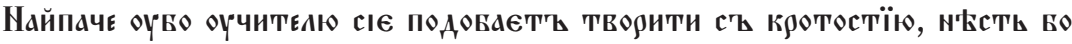

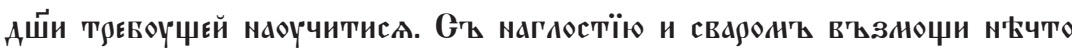

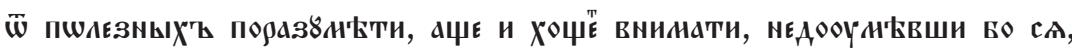

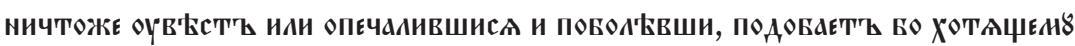

15 M. Starowieyski, Wstęp. Dialog o kaptaństwie, dz. cyt., s. 173.

16 M. Starowieyski, Wstęp. Dialog o kapłaństwie, dz. cyt.., s. 140.

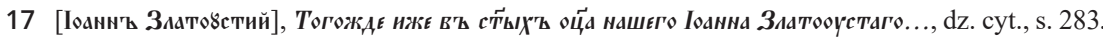

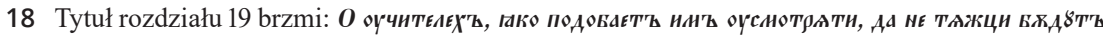
внегда оүчитт, но ваагопрїатни (s. 284-302).

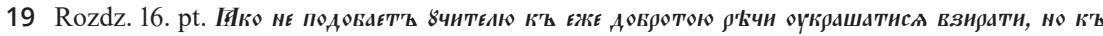
ЕЖе чТТ

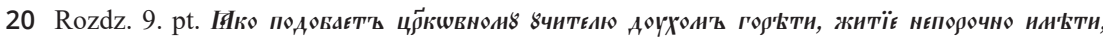

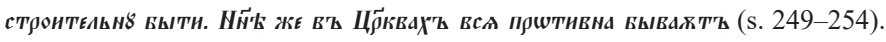

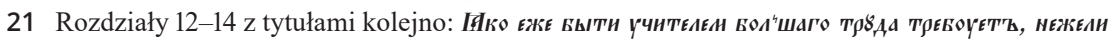

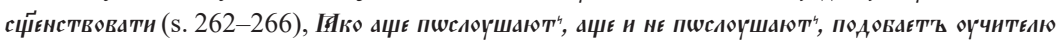

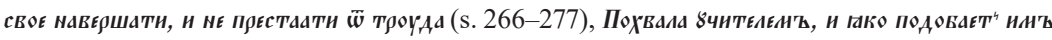
всл төъптти слова ради Бӝ̈̈а (s. 277-281).

22 Rozdział 21, s. 305-321. 


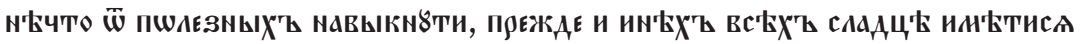

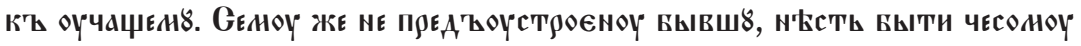

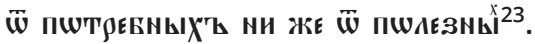

Ważne było, aby nauczyciel nie skupiał się w trakcie mowy na chwaleniu swojej cnoty, ale z pokorą starał się kształtować ją u swych podopiecznych ${ }^{24}$. Powinien też dawać zdecydowany odpór niegodnym wymaganiom

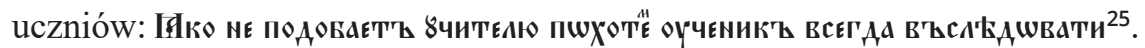

W obu dziełach św. Jana z lwowskiego tomu wybrzmiewał cytat z pierwszego listu św. Pawła do Tymoteusza, głoszący podwójną cześć tych kapłanów, którzy trudzą się ,głoszeniem słowa i nauczaniem” (Tm 5, 17): „Ifкo

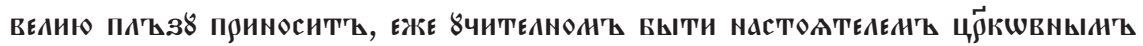

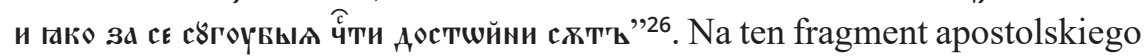
listu często powoływali się reformatorzy w metropolii kijowskiej ${ }^{27}$.

W paratekstach ksiąg cerkiewnych podejmowano także inne wyłożone przez Jana Chryzostoma w omawianych powyżej pracach tematy formacyjne. Wybierano najbardziej podstawowe problemy, a wśród nich postulowany już w Biblii i wielokrotnie w pismach ojców Kościoła obowiązek nauczania nie tylko słowem, ale i dobrym przykładem. Był to zalecenie dla głosicieli słowa Bożego, które wybrzmiewało w czasach reformy cerkiewnej szczególnie często $^{28}$. Sięgnął po ten argument m.in. biskup Arseniusz Żeliborski

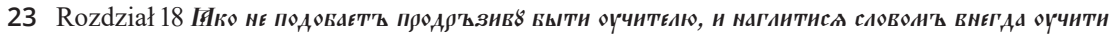
(s. 283).

24 Rozdział 16, por. przypis 15.

25 Rozdział 20, s. 302-305.

26 Jest to tytuł rozdziału 15, w którym biblijny cytat wybrzmiewa w kontekście problemu przygotowania kapłana do posługi słowa, por. s. 281-282. Por. także w Dialogu: „Аюв $\rho$ t

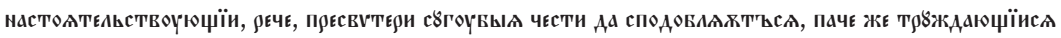

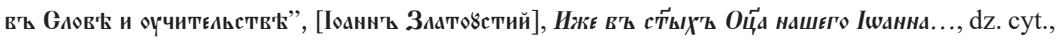
s. 141.

27 We lwowskich drukach pojawił się on m.in. w przedmowie do duchowieństwa zamieszczonej

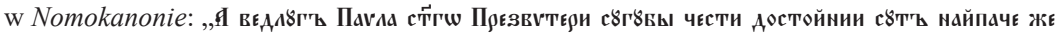

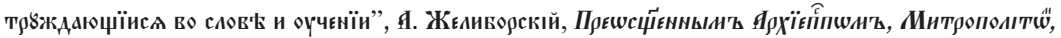

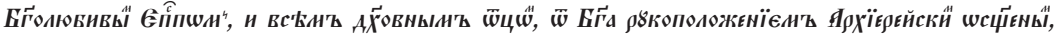

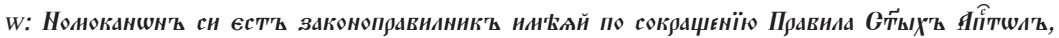

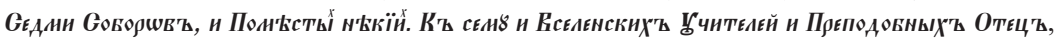
Лвов' 1646, k. 4.

28 Inne przykłady por. A. Z. Nowak, Źródła wiedzy dla kapłana-przedmowy w siedemnastowiecznych nomokanonach metropolii kijowskiej, w: Chrześcijańskie dziedzictwo duchowe narodów słowiańskich. Seria III, t. 2, Chrześcijaństwo w kulturze, sztuce i historii, pod red. Z. Abramowicz, K. Korotkicha, Białystok 2016, s. 299. 
w przedmowie do lwowskiego Nomokanonu (1646) - księgi kierowanej wyłącznie do odbiorcy duchownego - podkreślając rolę cnoty przepowiadacza

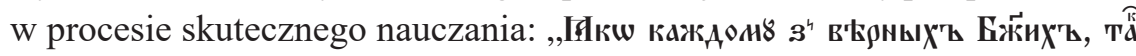

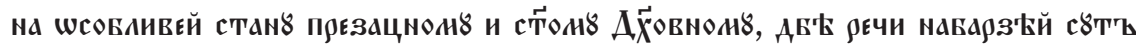

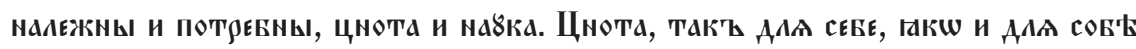
ПОдАЕГАЫГ"Ъ [...]"29.

Ten model etyczno-intelektualny propagował Symeon Stawnicki - drukarz lwowski w przedmowie do zbioru prac teologiczno-katechetycznych pt. Zwierciadło do obejrzenia i łatwiejszego zrozumienia wiary [...]. Powołał się on na autorytet św. Grzegorza, w którego pismach ${ }^{30}$ popularny w nauczaniu moralnym obraz lustra skojarzony został z postacią duszpasterza. Wierni, jak pisał w ślad za Ojcem wydawca, powinni wsłuchać się w zbawienne słowa nauczyciela i ,przeglądać się w jego dobrym postępowaniu” niczym

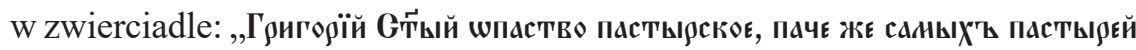

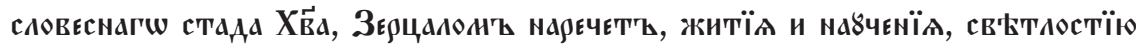

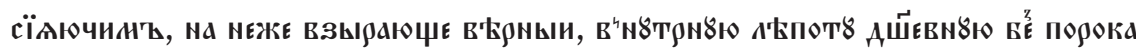
мог'чт" оүкрасити"з1.

Także inny świecki lwowski typograf - Michał Ślozka, autor wielu przedmów do duchowieństwa i listów dedykacyjnych do dostojników kościelnych, chętnie pouczał osoby duchowne, sięgając po cytaty biblijne i patrystyczne. W paratekście Apostoła z 1654 roku poświęcił uwagę roli władzy i znaczeniu nauczycielskiej posługi biskupa, który przewodnicząc duchowemu stadu, powinien wspierać je swą nauką i rozumem:

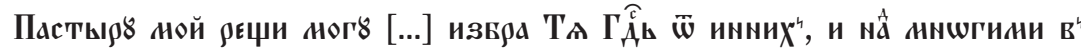

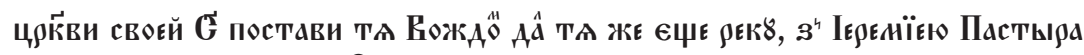

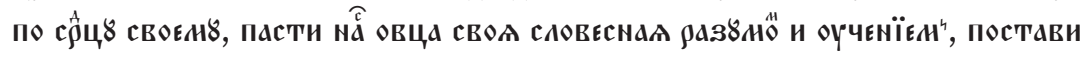

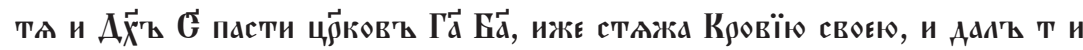

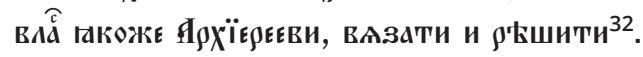

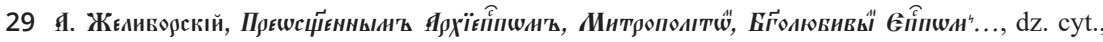
k. 2.

30 Prawdopodobnie przedmówca odwołuje się do siódmej księgi Moraliów św. Grzegorza Wielkiego.

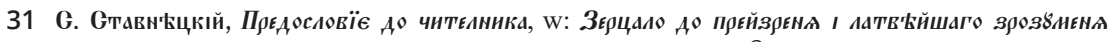

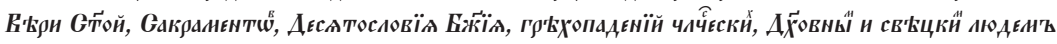
понинчнш, УОев' 1680, k. 2 nlb.

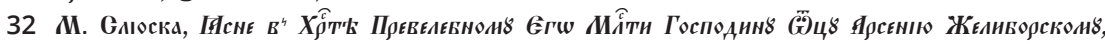

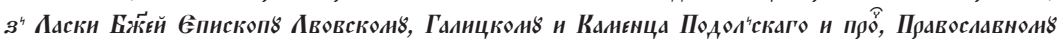

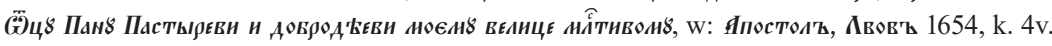


$\mathrm{Na}$ temat odpowiedniego przygotowania głoszących słowo Boże wypowiadał się również biskup lwowski, omawiając rozliczne posłannictwa kapłana. We wprowadzeniu do edycji Nomokanonu, uciekając się do popularnego w naukach dla kleru proroctwa Malachiasza $(\mathrm{Ml} 2,7)$ przypominał wszystkim głoszącym słowo Boże, że wymaga ono, aby ,wargi kapłana strzegły wiedzy”, bo tylko wówczas wierni będą ,szukali w nich pouczenia”:

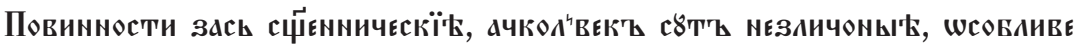

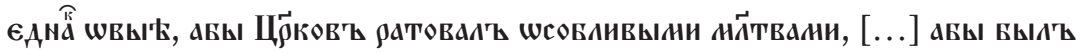

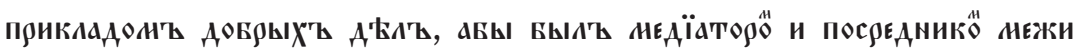

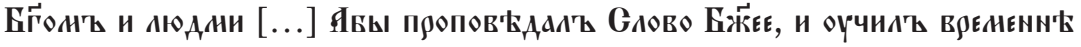

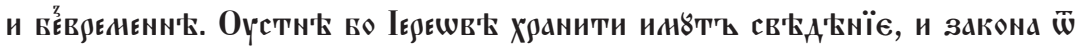

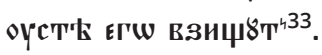

Edycje prac patrystycznych i ksiąg cerkiewnych realizowane w typografiach lwowskich - cenne źródła wiedzy formacyjnej dla duchowieństwa, były też wartościowym wsparciem tekstowym dla biskupa pouczającego kler, a zwłaszcza dla kapłanów realizujących tę posługę wobec wiernych. Drukarze i inicjatorzy wydań wskazywali na ten cel w paratekstach religijnych ksiąg.

W Apostole lwowskim z 1654 roku Ślozka zamieścił przedmowę do pobożnego czytelnika, która przeznaczona była jednocześnie dla duchowych i świeckich odbiorców ${ }^{34}$. Przekonywał, że powinni oni korzystać z wydanej księgi, czytając, ucząc się i rozwijając. Lektura Listów i Dziejów Apostolskich jest bowiem korzystna dla wszystkich odbiorców. Prezbiterzy dodatkowo dzięki niej odpowiednio przygotowują się do realizacji swego duchownego posłannictwa, jak wyraził to drukarz, powołując się na słowa św. Pawła do Tymoteusza (1Tm 4, 13-16):

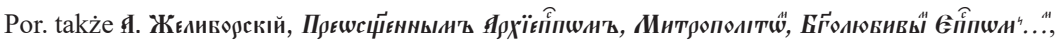
dz. cyt., k. $2 \mathrm{v}$.

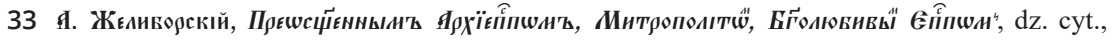
k. $3 \mathrm{v}-4$

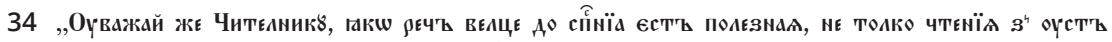

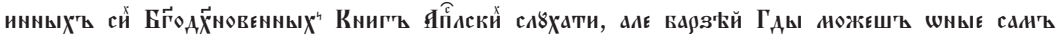

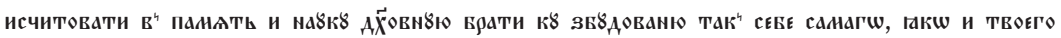
влижнагш", М. СлІоска, Побожнон४ и Х

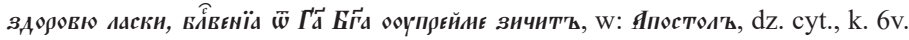


Не толһ КО в

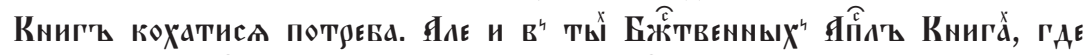

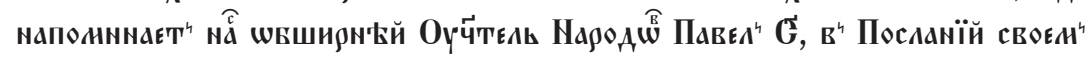

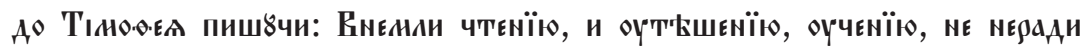

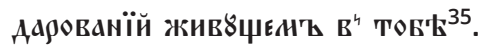

W poprzedzającej przedmowę dedykacji dla biskupa Arseniusza Żeliborskiego wydawca wygłosił pochwałę Apostoła, który jest nieprzerwanie od najdawniejszych czasów mocnym fundamentem nauk głoszonych przez ojców Kościoła i kaznodziejów, „rajskim kwiatem przynoszącym duchową strawę i napój sycący duchową mądrość, słońcem rozjaśniającym mroki niewiary":

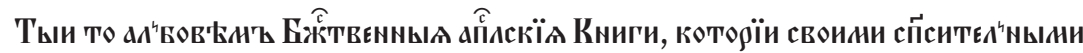

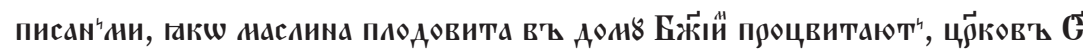

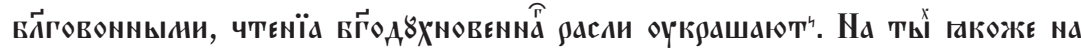

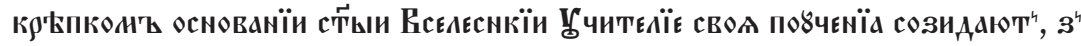

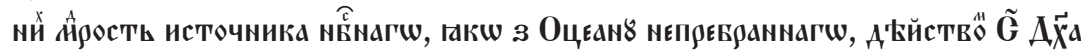

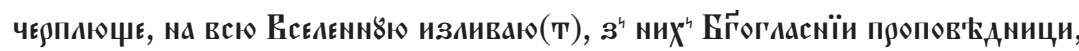

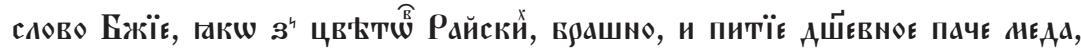

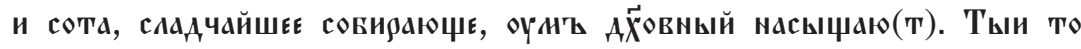

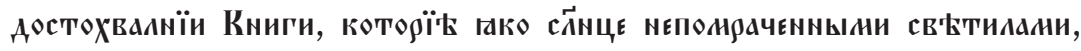

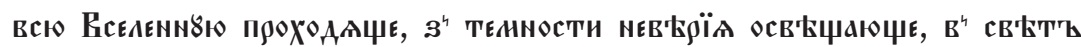

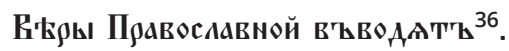

Biskup lwowski będący adresatem listu dedykacyjnego również podejmował wysiłki na rzecz udostępnienia drukiem prac, które mogły służyć nauczaniu. Przykładem służy zrealizowany w lwowskiej typografii brackiej przedruk nauki katechizmowej biskupa Sylwestra Kossowa (Дıдаскал̈а,

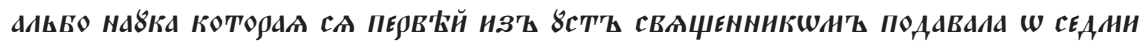

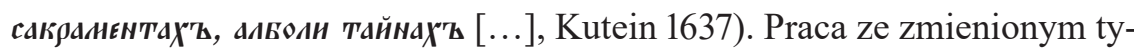

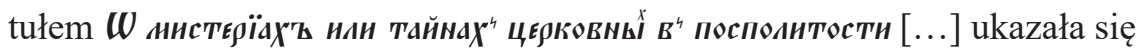

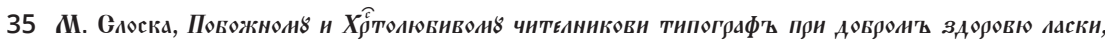

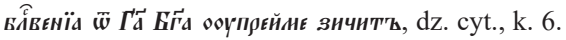

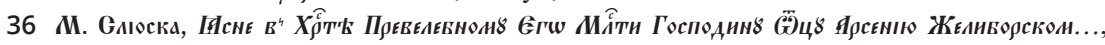
dz. cyt., k. 3 . 
w 1642 roku $^{37}$. Popularyzował ją także późniejszy biskup lwowski Józef Szumlański, umieszczając tę pomoc tekstową w składzie religijnego zbioru różnych użytecznych dla kleru prac, wydanych w Uniowie w 1680 roku $^{38}$.

W 1646 roku w nowo założonej typografii biskupa Żeliborskiego został wydany po raz trzeci tzw. Mały katechizm przygotowany rok wcześniej w środowisku kijowsko-pieczerskim. Lwowska wersja „prostą mową”

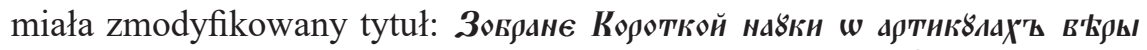

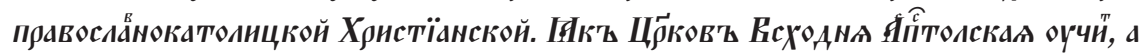
ААА ЦВИЧЕнА АКА АЙЙ НОАคА wą wydawcy. Władyka swoją decyzję o przedruku motywował faktem zbyt niskiego nakładu kijowskich edycji, przy jednoczesnym stwierdzeniu niezwykłej wartości tego katechizmu. Polecał go w pierwszej kolejności spowiednikom i nauczycielom, którzy, jak pisał, ,powinni rozumieć, że ich posłannictwem jest nauczanie powierzonych im wiernych i że jest to dzieło Boże”:

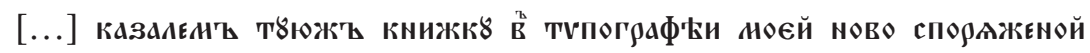

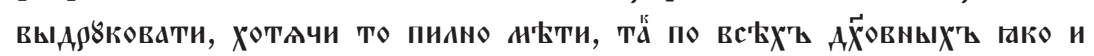

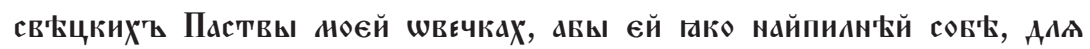

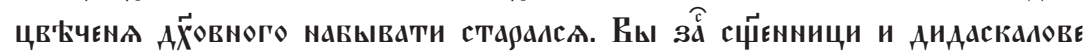

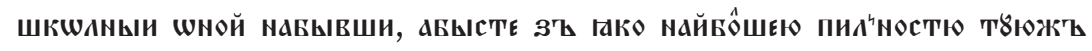

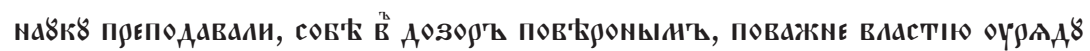

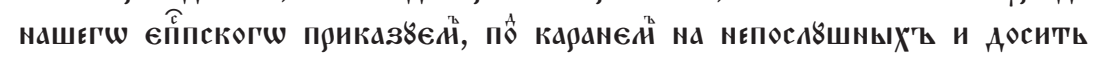

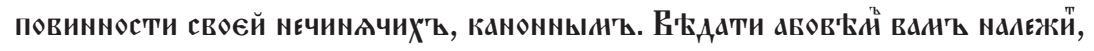

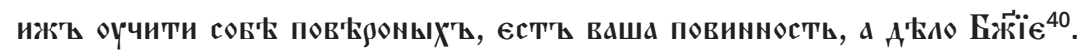

37 Przedruk tej wersji w: С. Голубев, Кіевскій митрополит Петръ Могила и его сподвижники, t. 2 (Приложенія), Кіевъ 1898, nr LVII, s. 206-226; оріs zabytku por. И. Каратаєвъ, Описаніе славяно-русскихъ книгъ, печатанныхъ кирриловскими буквами, t. 1: Съ 1491 по 1652 г., Санктпетербург 1883, nr 548; Я. Запаско, Я. Ісаєвич, Пам'ятки книжкового мистецтва. Каталог стародруків виданих на Украӥні, Львів 1981, s. 63, nr 297.

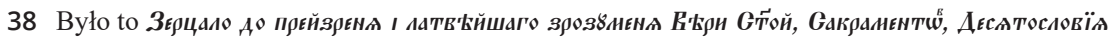

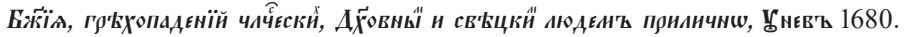

39 Pełny tytuł por. С. Голубев, Кіевскій митрополит..., t. 2 (Приложенія), nr LXXXI, s. 473; Я. Запаско, Я. Ісаєвич, Пам'ятки..., dz. суt., nr 350.

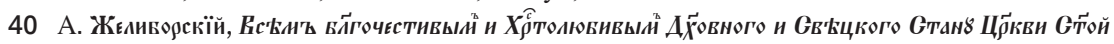

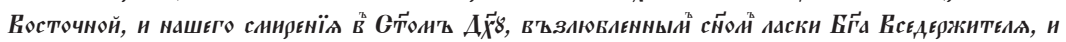

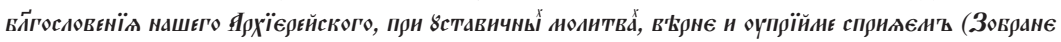
Колюткой наяки..., Авовъ 1646), w: С. Голубев, Кіевскій митрополит..., t. 2 (Приложенія), s. 474 . 
Zawartość treściowa nauk katechizmowych oraz ich dialogowa forma czyniła je poręcznym źródłem nauk głoszonych przez biskupa do kandydatów lub nowo wyświęconych księży, a przede wszystkim podstawą codziennej katechizacji wiernych. Edycje tych prac mogły pozytywnie wpływać na ożywienie zwyczaju przepowiadania, choćby w jego najprostszej i niewyszukanej odmianie, skoncentrowanej na utrwalaniu prawd wiary, przykazań, podstawowych modlitw ${ }^{41}$. W katechizmach definiowano istotę sakramentów, wskazując między innymi na posłannictwo i powinności osób przyjmujących kapłaństwo. Dla przykładu Krótki katechizm przypominał prezbiterom słowa

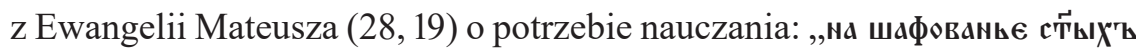

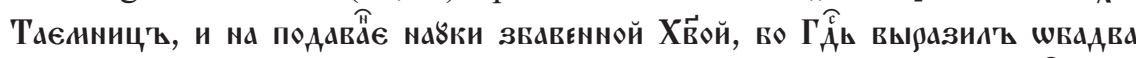

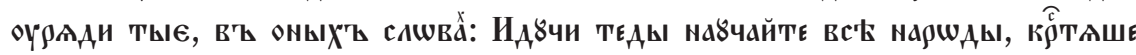

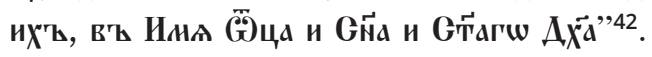

Warto pamiętać, że spod lwowskich pras wyszły również wzorcowe kazania okolicznościowe. Pomoce duszpasterskie w postaci pouczenia na okazję ślubu i pogrzebu zostały najpierw zamieszczone w Trebniku, który Ślozka wydał na zlecenie bractwa uspieńskiego w 1644 roku. Był to drugi w metropolii kijowskiej przypadek dołączenia wspomnianych materiałów do tej księgi liturgicznej ${ }^{43}$. Po raz trzeci te same kazania pojawiły się rok później w edycji zrealizowanej w typografii biskupiej (Lwów 1645).

Władyka Arseniusz, który był zaangażowany w przygotowanie wspomnianej wyżej księgi, przyczynił się do dwukrotnego wydania nauki dla

41 Potrzebę wsparcia posługi słowa w tak podstawowym zakresie potwierdza m.in. nauka Jakuba Suszy z 2. poł. XVII wieku, w której biskup apelował do duchowieństwa zgromadzonego na soborze o wykładanie wiernym katechizmowych modlitw i prawd wiary: „Повиненъ тыжъ честный отецъ намесникъ нашъ карати кождый єрей во церкви своей, абы оучили своихъ парафъянъ, Отче нашъ, Върую въ единаго Бога, Богородице Дъво, дестятеро Божіе приказаня [...]”, Я. Суша, Наука Соборовая и розные постановеня въ намғстництвп Спискомъ и Бтьикомъ и где индей поданыли (1669); przedruk fragm. w: В. Щурат, Два письма еп. Іннок. Винницкого. Причинок до істориї Западно-Рускої Церкви ХVII в., Жовква 1907, s. 9.

42 Cyt. za kijowską edycją: [П. Могила, I. Трофимович-Козловский], Оъвюанїє Колоткой Навки.

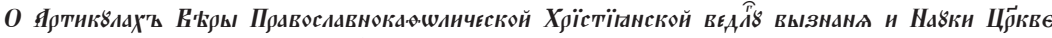

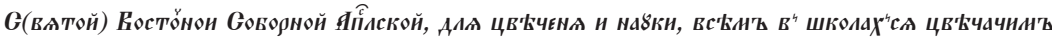

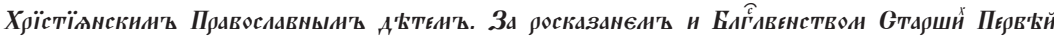

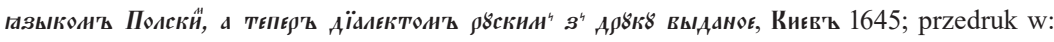
С. Голубев, Кіевскій: митрополитъ..., dz. суt., t. 2 (Приложенія), Кіевъ 1898, s. 417.

43 Pierwszy raz te kazania znalazły się w Trebniku wydanym przez bractwo wileńskie w 1621 roku, por. A. Z. Nowak, Priesthood in the Teachings for the Clergy. On the History of Religious Reform in the Kievan Metropolitanate throughout the 16th and 17th Centuries, Krakow 2017, s. 102, przyp. 320. 


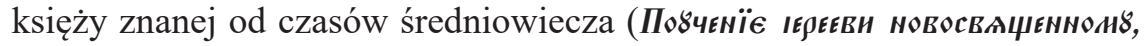

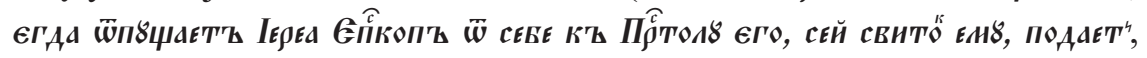
1642 i 1646 roku). I chociaż w tym tekście nie podjęto szerzej zagadnień związanych z posługą słowa, to jednak druk tego i wielu innych hierarszych pouczeń mógł mieć wpływ na odrodzenie zwyczaju głoszenia synodalnych i konsekracyjnych kazań do duchowieństwa ${ }^{44}$. Oczekiwanym przez konsekratorów rezultatem rzetelnego wypełniania nauczycielskich obowiązków wobec parafialnego kleru była odnowa moralna i intelektualna kapłanów przepowiadaczy słowa Bożego.

Lwowskie typografie już w pierwszej połowie XVII wieku podjęły starania o rozpropagowanie kaznodziejstwa i wzrost poziomu nauczania w metropolii kijowskiej. Zanim zaczęła działać bezkonkurencyjna na tym terenie jurysdykcyjnym typografia kijowsko-pieczerska, środowisko naukowe z lwowskiego bractwa uspieńskiego zdołało przygotować obszerne i starannie przemyślane dzieło przekładowe - Dialog i wybór homilii Jana Złotoustego wraz z dodatkiem pism innych ojców, dotyczących posługi duszpasterskiej. Dzieło to było kontynuowane w drugiej połowie XVII wieku zarówno w warsztacie brackim, jak i w krótko istniejących typografiach biskupich.

Reformatorzy lwowscy - m.in. poprzez dobór i druk odpowiednich patrystycznych dzieł przekładowych oraz niezbędnych ksiąg cerkiewnych, które eskortowane były przez nauki paratekstowe, przeznaczone dla kapłanów (w tym dla cerkiewnych nauczycieli) - prowadzili krucjatę na rzecz odnowy zwyczaju przepowiadania słowa Bożego. Włożyli również wiele wysiłku w uformowanie nauczycieli odznaczających się odpowiednim poziomem wiedzy i moralnymi walorami.

Starania te były ważną składową reformy podjętej także w innych ośrodkach oświatowo-wydawniczych (lub przez samodzielnych wydawców) i ukierunkowanej na odrodzenie nauczycielskiej posługi kapłana w metropolii kijowskiej.

44 Na temat biskupich pouczeń wypowiadali się niedawno Elena Bielakowa oraz Ihor Skoczylas. W przywołanej w powyższym przypisie książce wskazuję literaturę przedmiotu oraz omawiam rolę tych nauk w XVI-XVII-wiecznym odrodzeniu religijnym w metropolii kijowskiej, por. A. Z. Nowak, Priesthood in the Teachings..., dz. cyt., s. 50-63. 


\section{Bibliografia}

\section{Źródła}

Balaban" Aleksander", Starosta Věnnickï v" Hristě prevelebnomu otcu İeremievi Tisarovskomu z laski Božej Êpiskopu Lvovskomu, i pročâ̂, w: Iže v" svâtyh" Otca našeǵo İoanna Zlatoustaǵo arhïepiskopa Konstantinupolâ kniǵa o svâsen"stvě k" neiže v" kratcě s"brannoe žitie svâtoǵo i proča â nuždnaa v" obŝû polzu pročitatêlem pače že blaǵoǵověnnym iereom v" ispravlenïe priložena sut", Lvov" 1614, k. 3v-4 nlb.

[İoann" Zlatoustyj], Iže v" svâtyh" Otca našeǵo İoanna Arhïepiskopa Konstantìnaǵrada Zlatoustaǵo k" ukarâûsim" eže běžati svâŝenstva otvěŝatelno. O svâŝenstvě, w: Iže v" svâtyh" Otca našeǵo İoanna Zlatoustaǵo arhïepiskopa Konstantinupolâ kniǵa o svâsen"stvě k" neiže v" kratcě s"brannoe žitie svâtoǵo i proča â nuždnaa v" obŝûu polzu pročitatêlem pače že blaǵoǵověnnym" iereom" "v" ispravlenïe priložena sut", Lvov" 1614. [İoann" Zlatoustyj], Toǵožde iže v" svâtyh" otca našeǵo İoanna Zlatoustaǵo arhïepiskopa Konstantinopolâ o těh"žde, ih"že o svâsenstvě v"spomynaet" ot besěd" pače že ot âže na poslanïa Pavla Apostola, âže sut" svâsenstvu prilična, v" obŝû́ pl"zu svâsen"stvuûsim" izbrannyâ êklogi, w: Iže v" svâtyh" Otca našeǵo İoanna Zlatoustago arhiepiskopa Konstantinupolâ kniǵa o svâsen"stvě k" neiže v" kratcěs "brannoe žitïe svâtoǵo i pročaâ nuždnaa $v^{\prime \prime}$ obŝû polzu pročitatêlem pače že blaǵoǵověnnym iereom v" ispravlenie priložena sut", Lvov" 1614, s. 211-399.

Iže v" svâtyh" Otca našeǵo İoanna Zlatoustaǵo arhïepiskopa Konstantinupolâ kniǵa o svâsen "stvě k" neiže v" kratcě s"brannoe žitie svâtoǵo i pročaâ nuždnaa v" obŝû̂ polzu pročitatêlem pače že blaǵoǵověnnym iereom v" ispravlenïe priložena sut", Lvov 1614.

[Mogiila Petr", Tofimovič-Kozlovskij İsaâ], S"braniê Korotkoj Nauki. O Artikulah" Viry Pravoslavnokafoličeskoj Hrïstiânskoj vedluǵ vyznanâ i Nauki Cerkvê Svâtoj Vostočnoj Sobornoj Apostolskoj dlâ cvičenâ i nauki, vsěm" v" školah sâ cvěčačim" Hrïstïânskim" Pravoslavnym" dětem". Za roskazanêm" i Blaǵoslovenstvom" Starših" Pervěj âzykom" Polskim", a teper" dïalektom" ruskim" z" druku vydanoê, Kiev" 1645, w: S. Ǵolubev, Kievskì: mitropolit" Petr" Mogila i ego spodvižniki, t. 2 (Priloženìâ), Kìev" 1898, nr LXXXI, s. 359-469.

O misterïah" ili tajnah" cerkovnyh" v" pospolitosti [...], Lvov" 1642, w: S. Ǵolubev, Kievskì mitropolit Petr" Mogila i ego spodvižniki, t. 2 (Priloženìâ), Kìev" 1898, nr LVII, s. 206-226.

Slìoska Mìhail", Âsne v" Hristě Prevelebnomu Êho Milosti Ǵospodinu Otcu Arsenîu Želiborskomu, z Laski Božej Êpiskopu Lvovskomu, Galickomu i Kamenca Podolskaǵo i pročaâ. Pravoslavnomu Otcu Panu Pastyrevi i dobroděevi moêmu velice milostivomu, w: Apostol", Lvov" 1654, k. 2-5v.

Slìoska Mìhail", Pobožnomu i Hristoliubivomu čitelnikovi tipoǵraf" pri dobrom" zdorovû laski, blaǵoslovenïa ot Ǵospoda Boǵa uprejme zičit", w: Apostol", Lvov" 1654, k. 6r.-v. 
Stavněckìj Simeon, Predoslovïe do čitelnika, w: Zercalo do prejzrenâ i latvějšaǵo zrozumenâ Věri Svâtoi, Sakramentov", Desâtosloviä Božiâ, ǵrěhopadenï človečeskih", Duhovnym" i svěckim" lûdem" prilično, Unev" 1680, k. 2r.-v. nlb.

Suša Âkov", Nauka Soborovaâ i roznye postanovenâ v" naměstnictvě Spiskom" i Běckom" i gde indej podany (1669), fragm. v: V. Ŝurat, Dva pis'ma ep. İnnok. Binnickogo. Pičinok do istorï Zapadno-Ruskoï Cerkvi XVII v., Žovkva 1907, s. 7-12.

Želiborskïj Arsenïj, Preosvâsennym" Arhïepiskopom", Mitropolitom", Bogolûbivym" Êpiskopom", i wsěm" duhovnym" otcom", ot Boǵa rukopoloženiêm Arhïerejskim" osvjaŝennym, w: Nomokanon" si êst" zakonopravilnik" iměâ po sokraŝenüû Pravila Svâtyh" Apostolov", Sedmi Soborov" i Poměstnyh někïh. K" semu i Vselenskih" Učitelej i Prepodobny " Otec, Lvov" 1646, k. 2-6v.

Želiborskiij Arsenïj, Vsěm" blaǵočestivym" i Hrystolûbivym" Duhovnoǵo i Svěckoǵo Stanu Cerkvi Svâtoj Vostočnoj, i našeǵo smirenïâ v" Svâtom" Duhu, v"zlûblennym" synom" laski Boga Vsederžitelâ i blaǵoslovenïâ našeǵo Arhïêrejskoǵo, pri ustavičnyh molitvah", věrnê i uprïme spriâem" (Zobranê Korotkoj nauki...), Lvov" 1646, w: S. Ǵolubev, Kievskì mitropolit Petr" Moǵila i eǵo spodvižniki, t. 2 (Priloženîâ), Kìev" 1898, nr LXXXI, s. 473-475.

\section{Literatura}

Gudziak B. A., Kryzys i reforma. Metropolia kijowska, patriarchat Konstantynopola i geneza unii brzeskiej, Lublin 2008.

Harlampovič" K.V., Zapadno-russkiâ pravoslavnyâ školy 16 i načala 17 věka, Kazan' 1898.

Isaievych I., The Publishing Activities of the Confraternities, w: I. Isaievych, Voluntary Brotherhood Confraternities of Laymen in Early Modern Ukraine, Toronto 2006, p. 200 236.

Karataêv" I., Opisanie slavâno-russkih" knig", pečatannyh kirrilovskimi bukvami, t. 1: S" 1491 po 1652 g., Sanktpeterburg 1883.

Kuczyńska M., Homiletyka cerkiewna Pierwszej Rzeczypospolitej na pograniczu kultur (do polowy XVII wieku), w: Między Wschodem i Zachodem. Prawosławie i unia, pod red. M. Kuczyńskiej, Warszawa 2017, s. 196-237 (Kultura Rzeczypospolitej w Dialogu z Europą. Hermeneutyka Wartości, 11).

Lubac H. de, Wstęp. Teologia „Dialogu o kapłaństwie”, w: św. Jan Chryzostom, Dialog o kaptaństwie, przekł. W. Kania, oprac. M. Starowieyski, Kraków 1992, s. 5-20.

Nowak A. Z., Bracka oferta wydawnicza a odnowa kapłaństwa w Rzeczpospolitej-wybrane przykłady (pierwsza połowa XVII w.), w: Ośrodki kultury dawnej Stowiańszczyzny i ich znaczenie dziejowe, pod red. M. Kuczyńskiej, J. Stradomskiego, Kraków 2017, s. 181210 (Krakowsko-Wileńskie Studia Slawistyczne, 12).

Nowak A. Z., Priesthood in the Teachings for the Clergy. On the History of Religious Reform in the Kievan Metropolitanate throughout the 16th and 17th Centuries, Krakow 2017. 
Nowak A. Z., Reforma duchowieństwa wschodniego w Rzeczypospolitej w świetle ogólnego programu odnowy Kościoła, w: Między Wschodem i Zachodem. Prawosławie i unia, pod red. M. Kuczyńskiej, Warszawa 2017, s. 174-195 (Kultura Rzeczypospolitej w Dialogu z Europą. Hermeneutyka Wartości, 11).

Nowak A.Z., Źródła wiedzy dla kapłana - przedmowy w siedemnastowiecznych nomokanonach metropolii kijowskiej, w: Chrześcijańskie dziedzictwo duchowe narodów stowiańskich. Seria III, t. 2, Chrześcijaństwo w kulturze, sztuce i historii, pod red. Z. Abramowicz, K. Korotkicha, Białystok 2016, s. 283-301.

Starowieyski M., Wstęp. Dialog o kapłaństwie, w: św. Jan Chryzostom, Dialog o kapłaństwie, przekł. W. Kania, oprac. M. Starowieyski, Kraków 1992, s. 21-27.

Šustova Û. Ê., Dokumenty L'vovskogo Uspenskogo Stavropigijskogo bratstva (1586-1788): istočnikovedčeskoe issledovanie, Moskva 2009.

Zapasko Â., Ìsaêvič Â., Pam'âtki knižkovogo mistectva. Katalog starodrukìv vidanih na Ukraïnï̀, L'vìv 1981. 